\title{
Sustainability of The Riverside Settlements: The Case of Kampong Code and Kampong Sumeneban
}

\author{
Safilia Vinandita ${ }^{1}$, Nany Yuliastuti ${ }^{2}$ \\ \{safilia.vinandita16@pwk.undip.ac.id ${ }^{1}$, n.yuliastuti@pwk.undip.ac.id ${ }^{2}$ \} \\ ${ }^{1,2}$ Diponegoro University, indonesia
}

\begin{abstract}
Sustainability of the settlements has been a concern in the SDGs, especially goal no. 11. It focuses on ensuring adequate, safe, and affordable housing, increase the resilience toward disaster, as well as reduce the environmental impacts. Indonesia is one of the developing countries that has been facing the sustainability challenge of settlement in the form of slums. Many of them are found in the riverside area, which would threaten environmental sustainability in the long term. This study aims to explore the essential sustainability factors of the riverside settlement by comparing two cases, namely, Kampong Code and Kampong Sumeneban. Those kampongs have different conditions, where Kampong Code tends to be better than Kampong Sumeneban. The questionnaires have been distributed to 50 households in respective kampong to obtained the data. Also accompanied by the interview to the prominent persons of the kampongs. Scoring and descriptive statistical analysis have been carried out to answer the goal. The result shows that Kampong Code is more sustainable than Kampong Sumeneban. The most striking gap is found on ecological aspects and supports from other stakeholders. These points, further, would be essential to develop the more sustainable riverside settlement.
\end{abstract}

Keywords: Riverside, Settlement, Sustainability, Sustainable Development.

\section{Introduction}

Sustainable human settlement is essential in ensuring sustainable development. Goal no. 11 of the SDGs concerns to make cities and human settlements inclusive, safe, resilient, and sustainable [1]. This goal addresses the challenges of rapid urbanization in cities all over the world. Until now, about 3.5 billion people live in the urban area, and more than 5 billion people have been predicted to live in cities in 2030, especially in developing countries. Urbanization will lead to the emergence of informal settlements and slums and give stress to the first service provider. Besides, energy consumption and pollution will increase along with the urbanization [1].

In this regard, ensuring the sustainability of settlement is one point to achieve SDG goal 11 which should realize adequate, safe and affordable housing, increase the resilience toward disaster, as well as reduce the environmental impacts. Sustainable human settlement can be regarded as an ideal condition for future settlements. Three aspects of sustainability, i.e., the environment, social aspect, and the economy, are always the main pillars to be balanced in urban development. These aspects should be taken into account in settlement development, as mentioned that the development of settlement areas must comply with the regulations responsibly and sustainably [2]. Besides, sustainability should also emphasize on the environment as the central critical aspect [3]. One of the leading sustainability challenges in developing countries is the emergence of slums [1]. The phenomenon of urbanization has 
brought several issues that include the fast-growing number of the population, which has indirectly caused the growth of informal settlements [4]. It is about 883 million people living in the slum area, which mostly from eastern and southeast cities. Related to the slums, SDGs have proposed the target to create adequate, safe, and affordable housing.

The term informal in settlement context refers to the inhabitants' behavior in infringing formal rules, which might be land tenure, urban design, plan, or construction standards [5]. Many of the informal settlements have ended up to slums. This is because the inhabitants usually are impoverished people and only have a few choices. In many cases, they cannot access the land or even the essential services. This situation raises both severe environmental and social problems that Indonesia has been experiencing and making efforts to resolve the problem. Therefore, one target of goal 11 SDG is to reduce environmental impact [1].

In most developing countries, informal settlements or even slums can be found at the riverside. Many of them are unplanned settlements that have been developed since a long time ago before the spatial regulation has not been applied. Thus, it did not yet consider the environmental aspect in its development, such as river border provision or conservation area enactment which necessary to prevent ecological degradation and disaster. Also, the emergence of this settlement is caused by the outsiders who choose river banks to build their houses because they cannot afford the land price. The government usually tends to relocate them to other places or even does demolition. However, as a service to middle-low income people, slum upgrading will be an alternative to preserve those settlements.

River management has become a focus in Semarang City. It is listed in the 100 Resilient Cities as a strategy to achieve sustainable water and energy. There are three strategies, namely, increasing the performance of essential water management, promoting innovation in water provision, and promoting environmentally friendly behaviors. In order to attain these strategies, some initiatives related to the river management should be done, such as improve monitoring and imposing a better sanction for river pollution; essential water source conservation; optimize surface water utilization; promote grey water recycle technology and process waste to produce energy [1]. Therefore, river management is essential regarding the sustainability of the city.

In Semarang City, there is a riverside settlement, namely Kampong Sumeneban, which is classified as a slum area referring to KOTAKU (Kota Tanpa Kumuh/ City Without Slums) Program from the government. As in the study done by [6], it is found that the community has reduced awareness of the environmental issue, especially for river management. For example, bad behavior of throwing garbage in the river that will affect the stream, clog the water flow, and cause a flood in a specific area. Further, it would threaten the sustainability of this settlement.

Given that sustainability of the settlement in the riverside must be assured, it is essential to know what the essential sustainability factors of the riverside settlement are by comparing two cases with different preliminary indications. From this sight, the development can be more focused on the most critical aspects. 


\section{Sustainable Development and Riverside Settlement}

\subsection{A Concept of Sustainable Development}

One of the critical problems faced in economic development is how to deal with trade-offs between the development needs fulfillment on the one hand and the preservation of the environment on the other [7]. Economic development based on natural resources that do not pay attention to environmental sustainability will ultimately harm the environment itself because natural resources and environment have a limited carrying capacity. In other words, economic development that does not pay attention to the capacity of natural resources and the environment will lead to development problems in the future.

The concept of sustainable development has long since been a concern of experts. However, the term sustainability itself emerged a few decades ago. In a publication entitled The Limit to Growth by Meadow and his friends, economic growth would be significantly limited by the availability of natural resources [8]. With the limited availability of natural resources, the flow of goods and services generated from natural resources could not always be done sustainably.

Despite sharp criticism from economists for the weakness of the economic fundamentals used in The Limit to the Growth model, it is enough to make people aware of the importance of sustainable development. Consequently, the concern for sustainability is raised in 1987 when the World Commission on Environment and Development (WCED), published a book entitled "Our Common Future." This publication then triggered the emergence of a new agenda on the concept of economic development and its interconnection with the environment in the context of sustainable development.

This agenda is at once a challenge to the concept of neo-classical economic development which is a concept of healthy development that has been known, which stated that "sustainable development is one that meets the needs of the present without compromising the ability of the future generations to meet their own need. The development of sustainable development that meets the needs of the present without compromising the right to meet the needs of future generations" [9]. Sustainable development is a human effort to improve the quality of life by trying not to go beyond the ecosystem that supports life.

Generally, sustainability has three tenets that have been cited in many strategies for a long time, i.e., socially desirable, environmentally and ecologically sustainable, and economically viable and further reflect three principles of sustainability. Besides these three tenets, Barnard and Elliott added that technologically feasible, legally permissible and administratively achievable were suggested as a need to achieve successful, in marine environmental management as their case [10].

\subsection{Sustainability of The Settlement}


In the context of human settlement, several indicators are guided from three main aspects of sustainability. First, an environment that comprises building coverage, availability of green speech, greening behavior, using green technology, waste management, energy saving, liquid paste, green transportation [11]. A researcher also has the same opinion where the environmental sustainability can be seen from good accessibility and provision of adequate alternative transport modes like pedestrian, cycling and disabled access routes and public bus services, use appropriate land use plan for avoiding misuse and excessive use of land, human and financial resources, ensure the use of appropriate materials - sustainable and environmental friendly, for reducing maintenance and life-costs [12]. Meanwhile, another study has declared the other components such as disaster resistance, land use efficiency, high housing density, mixed land using, energy efficiency, water efficiency, adequate living spaces within small size unit, comfortable and healthy indoor environment, available green public spaces, effective waste management, adaptability and flexibility, reliability and durability, effectively utilizing resources, reduced footprint, minimize biodiversity loss [13], [14].

Second, the social aspect of sustainability consists of the community care about waste, community care about drainage, community involvement in an environmental case, the intensity of environmental conservation activities by the community, community social interaction, the performance of kelurahan administration in environmental care. It also about the equal distribution, social justice, gender equality, women empowerment, social cohesion, community participation in the decision making activities, skills acquisition and job opportunities, social services like public transport, health, education, security network, water and electricity, health and recreational facilities, sense of a place to live, public awareness about sustainable lifestyle [12]. Social aspect also about accessibility, equability and fairness of housing distribution, cultural and heritage conservation, community participation, sense of community, competent maintenance and management of properties, tenure security, minimize social segregation, maximize the wellbeing of workers, diversified housing types, social acceptability, suitability, harmonious social relationships, and increased consciousness of environment protection [14].

Third, economy aspects include the potential of household economic activity, household side job, waste utilization in household economic activity [11]. In line with that, a study was done to have a similar view about economic aspects, i.e., cost-effectiveness, desirability, affordable price/renting, reduced life-cycle cost, the balanced housing market, job opportunities, reduced transportation cost, and reduced energy bills [14].

Sustainability focus of the settlements located in the riverside is the environment. It is because the existence of riverside settlements, usually in the form of slums, may degrade the ecological function of the river and threaten their lives in the future. Some reasons are underlying this situation - first, the inhabitant's behaviors towards the environment. Since the water from the river is cheap, readily available and accessible from their homes, they use it for daily needs and activities [14], such as for bathing; washing dishes, clothes, vehicle or even throwing garbage and wastewater to the river which can pollute the river. Another study agreed that education about river management is essential in shaping community behavior to ensure sustainability [6]. 
The environment is divided into the natural environment and built environment. The natural environment is related to ecology, while the built environment is in the form of physical buildings, for example, infrastructure. Condition of settlements infrastructure, mainly, for solid waste management, sewerage system, and drainage system [6, 11]. Both solid waste and wastewater become the primary problem for the environment, especially the river [15]. The weak sewerage system which directly connected to the river is often causing the contamination of black water. While the substantial waste problem is caused by inhabitant's bad behavior, who throw garbage into river or drainage channels and clogs the flow of water [16], these will threaten the sustainability of the river as well as settlements. Therefore, proper waste management is needed in the riverside settlements to reduce littering into the river [17]. Kali Code, as riverside kampong, has experienced a kind of program, namely the Code Zero Waste Program and achieved zero waste [18].

Those problems of waste cause water quality to decrease. If this continues, it is doubtful whether the river can keep its ecological function usually or not for a long time. It will also raise health problems for those who consume the water from the river because it is contaminated. Another study considered this to measure the sustainability of the settlements [6]. The focus of environmental sustainability is global ecology, including the quality of water [16].

The presence of the river border is also critical to promote sustainability of riverside settlements. River border is a space between rivers and settlements in the form of vegetation or promenade. It serves to prevent erosion, pollution, and conserve the river. Besides that, ideal settlements have to provide green open spaces as water catchment area and community facilities to gather. Almost all slums experience lack of green open space because of limited land. Building green open space in the form of parks, home garden, or plants along the river and street is also a kind of beautification $[6,11,14,15]$.

The absence of a river border and vegetation leads to the disaster threat for settlements. This is compounded by bad community behavior, which dumps their garbage into water. It causes siltation of the river and clogs the flow of water. Hence, the frequent disasters in the Riverside area are flood, landslide, and another climate change-related disaster [3]. The flood is inevitable because water will rise during the rainy season [19]. In this case, the adaptation from inhabitant in dealing with disaster should be taken into account as a measure to achieve sustainability in the future $[19,20]$.

Another factor in ensuring sustainability is community awareness towards the environment. The awareness can be represented by community understanding upon ecology and ecosystem [20]. It makes them know how it should be done when encountering the dynamics of the ecosystem. For example, they prepare their actions to handle the disaster, e.g., flood, which may occur at any time [4]. In order to mitigate, since they understand that the impact of throwing garbage into the river will make the river shallow, they prevent to do this and participate in promoting environmental care. A study also conveyed that continuous and extensive community participation is central to the social aspect of river restoration [21]. At the highest level of awareness, there is a possibility where the community gather, make an institution, and take collective action [20]. 
Besides community movement, the external supports, i.e., the role of local government and other stakeholders are also important. The actions from the community will be hampered without any support from the government, for example, in program facilitation and funding. The government and other stakeholders such as a university, private sectors, and NGO have a role in empowering the community by coordinating them in a formal institution [2]. The interaction between interest groups, especially for the community with other groups, is also a crucial issue to be considered [20]. First, it is because the community can organize local information and local knowledge. The second is the fact that engages the community in development can grow their sense of belonging, which is essential to ensure the sustainability of the programs $[18,20]$. The importance of external support has been proven by the success of Romo Mangun, who tried to improve Kampong Code [18]. The capacity of the community to work together with other stakeholders; in this case, their acceptance, will help the program run well.

\section{Research Method}

This study used a quantitative method on data collection. The data was collected by distributing a questionnaire. It is done to 50 households chosen randomly as a sample for each kampongs. The population is the inhabitants living there. The questionnaire contains several questions referring to the variable indicators. There are five options in a question which each option has its score that shows the respective value of the answer. In addition to questionnaire distribution, interview with representatives has been carried, in this case, local leaders who know more about their settlement area. The sample size used is 50 determined by the specific calculation. Quantitative analysis is performed, i.e., scoring, descriptive statistical analysis, and the comparative method. The scoring method is used to measure all variables with the scale from 1 to 5 . The final analysis has been done with a comparative approach in two different cases of riverside settlement in order to find the most significant gap in sustainability factors.

\section{Result and Discussion}

As in the initial indication described before, Kampong Code is more sustainable than Kampong Sumeneban based on its general conditions and accomplishments. The sustainability research is performed to strengthen this statement by comparing it to another less sustainable case, Kampong Sumeneban, with equated indicators. It is focused on five sustainability tenets, i.e., physic, ecology, social, economy, as well as policy and external support. The score recapitulation of the particular aspect can be seen in Table 1 below, and the bold number shows the higher score.

Table 1. The Score Summary of Sustainability of the Settlements

\begin{tabular}{llcc}
\hline \multicolumn{2}{c}{ Rated Aspect } & Kampong Sumeneban & Kampong Code \\
\hline \multirow{3}{*}{ Physical Aspect } & Infrastructure and & 2.86 & $\mathbf{3 . 5 8}$ \\
& Facilities Condition & $\mathbf{3}$ & 2.5 \\
\cline { 2 - 4 } Ecological Aspect & Building Coverage & 2 & $\mathbf{5}$ \\
\cline { 2 - 4 } & Quality of River Water & 3 & $\mathbf{4}$
\end{tabular}




\begin{tabular}{llccc}
\hline & Rated Aspect & Kampong Sumeneban & Kampong Code \\
\hline & \multicolumn{1}{l}{ Natural Disaster } & 4 & 4 \\
\cline { 2 - 4 } & $\begin{array}{l}\text { Social Bond to The } \\
\text { Community }\end{array}$ & 4.58 & $\mathbf{4 . 9 2}$ \\
& $\begin{array}{l}\text { Community Awareness } \\
\text { Cocial Aspect }\end{array}$ & 2.51 & $\mathbf{2 . 5 3}$ \\
& $\begin{array}{l}\text { Collective Action on The } \\
\text { Economic Aspect }\end{array}$ & 2 & $\mathbf{4}$ \\
\cline { 2 - 4 } Policy ander Management & The Living Cost & 3.44 & $\mathbf{4 . 0 9}$ \\
\cline { 2 - 4 } External Support & Environmental Policy & 2 & $\mathbf{5}$ \\
\hline
\end{tabular}

Author's Analysis, 2019

On the whole, the scores of Kampong Code is higher than Kampong Sumeneban. Only in the case of building coverage where Kampong Code got the lower score because the density of the buildings is higher than Kampong Sumeneban.

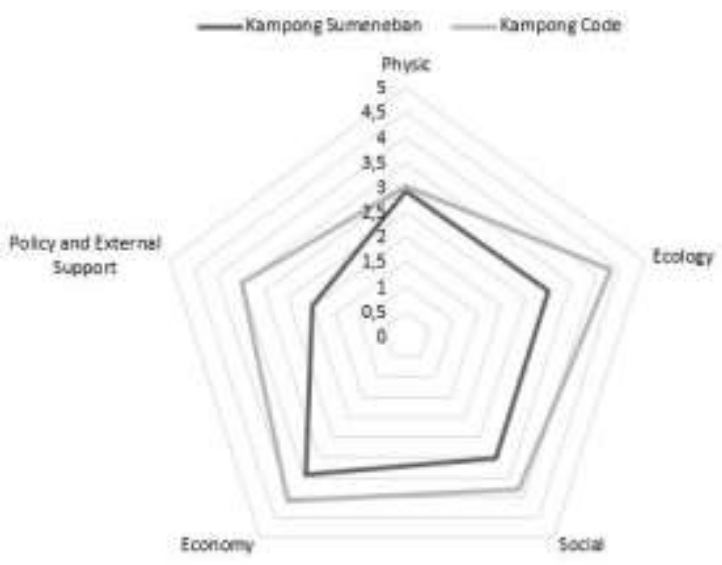

Fig. 1. The Sustainability of Kampong Sumeneban and Kampong Code

The result proves that Kampong Code is more sustainable than Kampong Sumeneban according to the score obtained. It is presented in Figure 1 that Kampong Code has a higher score for almost all aspects. The similarity of the score is found in the physical environment. This is because, physically, both kampongs have similar built-environmental conditions. It is represented by the condition of infrastructures and facilities such as road, waste management system, drainage system, sewage system, and social facilities. Besides, the building coverage also becomes an indicator to measure it.

The environment would also be sustainable when it has a good quality ecology. Since the settlements are focused on the riverside area, the element of ecology contains the river and the activities in it. It is also related to the natural disaster threat. Kampong Code tends to have better ecology condition in terms of its good river quality and people's behavior. The water looks clearer and flows well. While the wastewater covers the river in Kampong Sumeneban in the form of greyish foam and has a bad smell. Ketua $R W$ (the leader of this kampong) conveyed that people still wash and dispose of the waste to the river. However, the condition 
is much better than the past, where the river was full of garbage. Figure 2 shows the difference of river condition in both areas. The left picture is Kali Semarang (Semarang River) in Kampong Sumeneban and the right one is Kali Code (Code River) in Kampong Code.

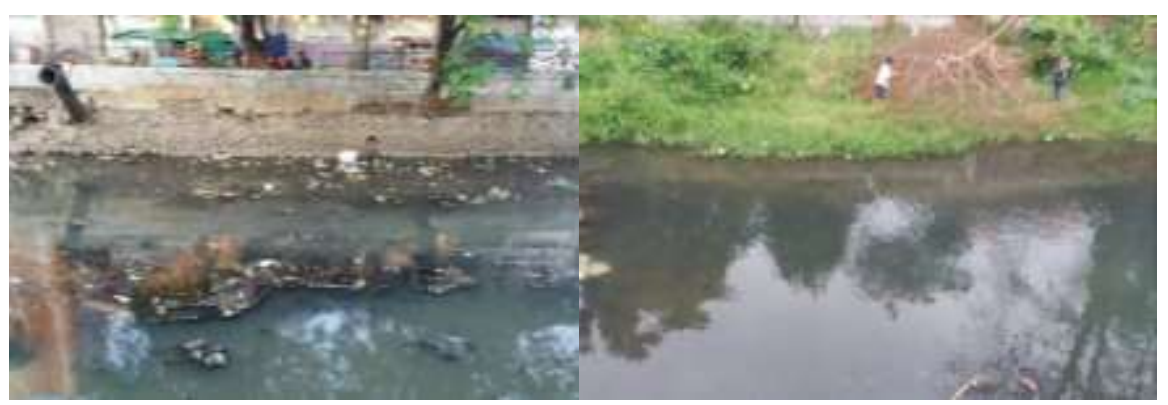

Fig. 2. The Comparison between Kali Semarang (left) and Kali Code (right)

Disaster resistance also shows the sustainability of a settlement [14], [16]. It is noted that there are natural disaster threats on both kampongs. The global threat is flooding that might come from the overflowed river. Kampong Sumeneban has never experienced flood for the past few years because the government made several efforts to avoid the flood, for instance, installing water pumps, widening drainage channels and developing an information system for the disaster. Hence, people feel insecure and do not have a specific action to tackle the flood. Kampong Code has different circumstance. This kampong has experienced mud flood from a volcanic eruption in 2006 and 2010. Learning from those experiences, people become more aware. They have prepared mitigation and adaptation strategies even though they are not so worried about the disaster at this time.

Its community influences the sustainability of a settlement in the social aspect. People living in Kampong Code and Kampong Sumeneban have different characteristics, and it affects their social life. Although the people in both kampongs have been living there for a long time, the inhabitants in Kampong Code was lived longer, and they build a good relationship among inhabitants as well as actively participated in their events. Their social bond is getting tighter because they share the same sentiment. Kampong Sumeneban got a lower score on social bond because some of the inhabitants are not living there. They chose to live with their family in other places. The others use their land for individual businesses considering that Kampong Sumeneban is located in the strategic area (trading center). Several buildings are used as warehouses, while they live in another place with a better environment. Even some of the owners are not the indigenous people. Therefore, the social capital is not as high as Kampong Code since the inhabitants are an individualist. The collectivistic culture in Kampong Code is stronger than Kampong Sumeneban.

The economic sustainability is not only measured by a particular unit of measurements such as family income and expenditure, but it also depends on their ability to pay the living costs. In fact, there is a similarity between family income in Kampong Code and Kampong Sumeneban. There are some activities related to home production in Kampong Sumeneban, which can be classified as a good step for sustaining the settlement economically. It can be concluded that this kampong has better competitiveness. With this reason, people become more individualistic socially. Still, their low education and skill become an obstacle in developing their businesses so that their income has not increased significantly. In terms of living cost affordability, people in Kampong Code are abler to meet their needs, especially for property tax, transportation, and energy bills. It might be because of their excellent financial 
management.

The highest range score is found on the point of policy and external support. Kampong Code and Kampong Sumeneban have the same environmental policy or regulation in the level of the kampong. However, the difference is in the external support from other parties. Kampong Code has got more attention since Romo Mangun stood up for its existence. His contribution to welfare improvement was made by empowering the community. First, he changed the mentality of community in the riverbanks to eliminate their bad habit of littering the river. Romo did it by living with them for six months, giving examples through oral and actions on how to care for the environment. Now, people are still remembering his messages, including preserving their house form to face the river. Afterward, other parties also contributed to improving the environmental and social quality of the village.

\section{Conclusion}

As initial indication, Kampong Code is concluded as more sustainable riverside settlement than Kampong Sumeneban according to the whole aspects. Although specifically building coverage score, which is a part of the physic element, of Kampong Code is lower than Kampong Sumeneban, it can be explained from the cultural views. For instance, the buildings that cannot be changed because it is Romo's legacy and becomes a cultural asset. The assessment of the rest aspects shows that Kampong Code has better or same condition.

Referring to the calculation, the greatest range of scores is spotted on the river quality and the assistance from other parties. It indicates that those factors influence the sustainability gap between two kampongs most. River quality is the main ecological element in the riverside settlement that should be kept well to ensure the sustainability of the kampong. The river condition in both kampongs are quite different as explained above. Not only the cleanliness of the river, but also the quality of the water. People behavior also takes important role to manage the river. In this case, the standing of river quality in sustaining the settlement can be discerned from health and natural disaster issues. Health is associated with the water to consume and the natural disaster with how the river perform its ecological function.

Meanwhile, assistance from external parties is also essential to develop both environment and socio-economic. It can be related to the community empowerment. Kampong Code is an example of the success of empowerment conducted by Romo Mangun. After thirty-six years, the community still remembers the knowledge and advice from him related to the kampong's management. The assistance from other parties are still carried out until now especially in the field of health and education. Through this assistance, it is expected that the community could be more empowered and independent.

These two factors need to be considered in developing riverside settlements because it will be the most decisive aspects in ensuring sustainability. Even so, the other aspects should not be underestimated because it has respective roles in sustaining the riverside settlement

\section{Acknowledgment}

The author would like to thank Urban and Regional Planning Department for the facilitation, communities in both kampongs and all the parties who have helped and contributed during the research as well as Mr. Agung Sugiri for the valuable knowledge he shared. 


\section{References}

[1] UN-Habitat, MONITORING FRAMEWORK, SDG Goal 11: A GUIDE TO ASSIST NATIONAL AND LOCAL GOVERNMENTS TO MONITOR AND REPORT ON SDG GOAL 11. 2016.

[2] B. Widodo et al., "Analysis of environmental carrying capacity for the development of sustainable settlement in Yogyakarta urban area," Procedia Environ. Sci., vol. 28, pp. 519-527, 2015.

[3] S. Schetke, D. Haase, and T. Kötter, "Towards sustainable settlement growth: A new multi-criteria assessment for implementing environmental targets into strategic urban planning," Environ. Impact Assess. Rev., vol. 32, no. 1, pp. 195-210, 2012.

[4] A. El Menshawy and S. Shafik, "Affordable Housing as a Method for Informal Settlements Sustainable Upgrading," Procedia-Social Behav. Sci., vol. 223, pp. 126133, 2016.

[5] K. Dovey, "Sustainable informal settlements?," Procedia-Social Behav. Sci., vol. 179, pp. 5-13, 2015.

[6] Z. S. Kusharsanto and A. Sugiri, "Kajian Perilaku Masyarakat dalam Kaitannya dengan Fungsi Ekologis Kali Semarang di Kampung Purwodinatan dan Sumeneban," Tek. PWK (Perencanaan Wil. Kota), vol. 2, no. 3, pp. 649-660, 2013.

[7] A. Fauzi, Ekonomi sumber daya alam dan lingkungan: Teori dan aplikasi. Gramedia Pustaka Utama, 2004.

[8] D. H. Meadows, D. L. Meadows, J. Randers, and W. W. Behrens, "The limits to growth," New York, vol. 102, p. 27, 1972.

[9] S. W. S. WCED, "World commission on environment and development," Our common Futur., vol. 17, pp. 1-91, 1987.

[10] S. Barnard and M. Elliott, "The 10-tenets of adaptive management and sustainability: an holistic framework for understanding and managing the socio-ecological system," Environ. Sci. Policy, vol. 51, pp. 181-191, 2015.

[11] N. Yuliastuti, H. Wahyono, S. Syafrudin, and S. Sariffuddin, "Dimensions of community and local institutions' support: Towards an eco-village kelurahan in Indonesia," Sustainability, vol. 9, no. 2, p. 245, 2017.

[12] A. O. Oyebanji, C. Liyanage, and A. Akintoye, "Critical Success Factors (CSFs) for achieving sustainable social housing (SSH)," Int. J. Sustain. Built Environ., vol. 6, no. 1, pp. 216-227, 2017.

[13] E. S. (ed) Ekadjati, Direktori Naskah Nusantara. Jakarta: Yayasan Obor Indonesia., 2000.

[14] X. Gan, J. Zuo, P. Wu, J. Wang, R. Chang, and T. Wen, "How affordable housing becomes more sustainable? A stakeholder study," J. Clean. Prod., vol. 162, pp. 427437, 2017.

[15] P. Tutuko, E. Subagijo, and N. Aini, "The Planning and Design of Residential Facilities in Poor Areas with Limited Land," Int. Rev. Spat. Plan. Sustain. Dev., vol. 6, no. 3, pp. 22-36, 2018.

[16] E. Ryanti, N. Hasriyanti, and W. D. Utami, "Design principles of water sensitive in settlement area on the river banks," in IOP Conference Series: Earth and Environmental Science, 2018, vol. 126, no. 1, p. 12035.

[17] V. Yogiesti, S. Hariyani, and F. R. Sutikno, "Pengelolaan sampah terpadu berbasis masyarakat Kota Kediri,” J. Tata Kota dan Drh., vol. 2, no. 2, pp. 95-102, 2012. 
[18] L. Natadjaja and P. B. Setyawan, "Improving the living standard of community in Code riverside through environmental natural resources utilization," 2013.

[19] R. Rachmawati, E. Prakoso, M. I. Sadali, and M. G. Yusuf, "Riparian planning in Yogyakarta City Riparian planning in Yogyakarta City," in IOP Conf. Series: Earth and Environmental Science 148, 2018.

[20] C. Seftyono, "Kali Code: From Merapi to Sustainable Society," in International Conference on Sustainable Innovation, 2012.

[21] R. J. Chou, "Achieving successful river restoration in dense urban areas: Lessons from Taiwan," Sustain., vol. 8, no. 11, 2016. 